\title{
Article
}

\section{The impact of coping style, self-efficacy, emotional reaction and resilience on trauma related intrusive thoughts}

McBride, Hazel and Ireland, Carol Ann

Available at http://clok.uclan.ac.uk/14077/

McBride, Hazel and Ireland, Carol Ann ORCID: 0000-0001-7310-2903 (2016) The impact of coping style, self-efficacy, emotional reaction and resilience on trauma related intrusive thoughts. Journal of Forensic Practice, 18 (3). pp.

229-239. ISSN 2050-8794

It is advisable to refer to the publisher's version if you intend to cite from the work. http://dx.doi.org/10.1108/JFP-06-2015-0036

For more information about UCLan's research in this area go to http://www.uclan.ac.uk/researchgroups/ and search for <name of research Group>.

For information about Research generally at UCLan please go to http://www.uclan.ac.uk/research/

All outputs in CLoK are protected by Intellectual Property Rights law, including Copyright law. Copyright, IPR and Moral Rights for the works on this site are retained by the individual authors and/or other copyright owners. Terms and conditions for use of this material are defined in the policies page. 
The impact of coping style, self-efficacy, emotional reaction and resilience on trauma related intrusive thoughts

\author{
Hazel McBride*
}

HMP Edinburgh, Scottish Prison Service

\begin{abstract}
Carol A. Ireland
Ashworth Research Centre, Mersey Care NHS Trust, School of Psychology, University of Central Lancashire, UK and CCATS: Coastal Child and Adult Therapeutic Services, UK
\end{abstract}

Corresponding author Hazel McBride at $\underline{\text { Hazel.McBride@sps.pnn.gov.uk }}$ 


\begin{abstract}
Purpose - This study aims to explore the impact of coping style, self-efficacy, resilience and emotional reaction of trauma related intrusions in young offenders.

Design/methodology - This is a quantitative study using questionnaires. The sample was 152 young offenders in custody who were approached in their residential hall. Upon agreeing to participate they were given 24 hours to complete the questionnaire pack and returned these to the researcher at a designated time and place.

Findings - Over $90 \%$ of the sample indicated at least one traumatic event; $33.6 \%$ indicated 8 or more. Number of traumatic events did not impact on self-efficacy, resilience or coping strategy used. The type of coping strategy did not significantly impact on emotional reaction to intrusions across trauma groups. Participants with higher self-efficacy demonstrated greater problem-focused coping and less emotional reaction to intrusions. Participants with greater resilience scores utilised more problem and emotion-focused coping and experienced less emotional reaction to their intrusions. Resilience was predicted by self-efficacy and emotional reaction to intrusions.
\end{abstract}

Practical implications - Professionals working with young offenders with trauma related intrusions should focus on building strengths in the areas of problem-focused coping, selfefficacy and resilience.

Originality/value - This paper adds to the literature on trauma in male young offenders by looking at psychological factors which could be developed upon to improve ability to manage intrusive thoughts.

Keywords- Trauma, intrusive thoughts, coping style, self-efficacy, resilience, young offenders Article Classification - Research paper

\title{
Introduction
}

Trauma is viewed as an emotional reaction to a serious event such as an accident, rape or natural disaster (APA, 2013). In severe cases this can lead to Post Traumatic Stress Disorder (PTSD), characterised as re-experiencing, avoiding reminders, and/or cognitive distortions about the event and those involved, overwhelming negative moods, and increased 
arousal (APA, 2013). Even without PTSD people may be traumatised by an event that can impact and interfere with their lives. It can cause symptoms such as overwhelming negative feelings, mistrust of others, difficulty in relationships, and intrusive thoughts about the event (Margolies, 2010).

Offender populations have a high prevalence of trauma (research suggests between 60\% and 92\%: Moore, Gaskin \& Indig, 2013; Abram et al, 2013). In studies of antisocial youth, self-reported trauma ranges from $70 \%$ to $92 \%$ (McMackin, Morrissey, Newman, Erwin, \& Daley, 1998; Rivera \& Widom, 1990; Steiner, Garcia, \& Matthews, 1997); with indications that $24 \%$ to $65 \%$ have PTSD (Burton, Foy, Bwanausi, Johnson, \& Moore, 1994; Cauffman, Feldman, Waterman, \& Steiner, 1998; McMackin et al, 1998; Steiner et al., 1997; Wood, Foy, Layne et al., 2002). 84\% of juvenile offenders in America had experienced more than one trauma and that $56.8 \%$ were exposed to 6 or more traumatic events (Abram et al, 2004). These findings indicate that trauma is a prevalent feature in young offenders. Literature in this area often focusses on individuals with mental illness or on female offenders which limits generalizability. Associated risk factors (e.g. neglect, poverty related violence, substance use, ineffective parenting) and risk taking behaviours increase the opportunities for young offenders to be exposed to events which could lead to trauma (Greenwald, 2002). As such, this study will look at the levels of trauma in male young offenders. This will focus on their coping styles, emotional reaction, self-efficacy and resilience when faced with intrusive trauma-related thoughts.

Outside of forensic populations, trauma in young people is particularly relevant due to the widespread effects it can have on biological and social development (Van der Kolk, 2005). Multiple trauma during developmental phases can lead to maladaptive coping and anti-social behaviour (Van der Kolk, 2005). The ability to recover psychologically from trauma is dependent on many factors including pervasiveness, length of time exposed, the context of the trauma, personality/coping style and pre and post-trauma environmental factors (Harris \& Howard, 2014). Therefore understanding the effects of trauma and identifying those factors that can impact positively on its management has relevance to professionals engaging with young offenders. 
Cognitive processing models of trauma provide an explanatory framework for the difficulties individuals have in managing responses to their experience. Traumatic events and related intrusions can disrupt functional thinking, produce maladaptive thinking and have a negative impact on problem solving as they interrupt how we process or cope with the trauma (Greenberg, 1995; Creamer et al, 1992; Lyubomirsky \& Nolen-Hoeksema, 1995; NolenHoeksema, Parker \& Larson, 1994). A criticism of this model has been that it underestimates the strength and endurance of affective responses to trauma (Litz, 1992). Research has found that experiencing above average intrusive thoughts about stressors strengthened affective reaction to stress, especially in younger adults (Brose, Schmiedek, Loveden \& Lindenberger, 2011). Intrusive thoughts are disruptive to cognitive processes and therefore suggest that they also impact a person's ability to utilise problem-focused coping strategies. Consequently there is an increased reliance on emotions (Clark, 2005; Berry et al, 2010). It has also been reported that young offenders who exhibit emotional reaction to traumatic events are relying on ineffective coping strategies (Zamble \& Quinsey, 1997). It is important to research emotional reaction to intrusive thoughts and coping strategies as it can help inform our understanding how young offenders manage their traumatic experiences (Berry et al, 2010).

Coping strategies can help young offenders manage difficult situations however it has been suggested that these strategies can change over time depending on their situation (Brown \& Ireland, 2006). After using a coping strategy the individual may review how effective this was and make appropriate changes (Folkman \& Lazarus, 1985). Reductions in emotion coping and increases in detachment coping were found in a sample of young offenders over a 6 week period after incarceration when managing distress (Brown \& Ireland, 2006). This would suggest that coping style changes to more adaptive strategies to deal with current position of custody and to manage emotions. Problem-focused coping strategies may help individuals feel more in control of their intrusive thoughts and therefore more able to regulate emotions (Goldin et al, 2009). The type of coping strategy used may be effective for the current situation however development of effective coping strategies could affect the way that a person manages their cognitive and affective responses to trauma long-term.

As well as coping, resilience (the ability to adapt successfully to stressful situations while maintaining normal psychological functioning $(\mathrm{Wu}$, Feder, Cohen, Kim, Calderon, Charney \& Mathe, 2013) could also play a role in influencing differences in response to intrusive thoughts. Campbell- Sills and colleagues (2006) investigated coping strategies, 
resilience and personality constructs in undergraduate students. They found that coping styles predicted variance in resilience over and above the contributions of personality traits. They also found that problem-focussed coping was positively related to resilience whereas emotion-focused coping was associated with low resilience which is supported by findings in other studies (Feder, Nestler \& Charney, 2009; Troy, Wilhelm, Shallcross \& Mauss, 2010). However the sample had a relatively low incidence of trauma and this could be skewing the results.

Resilience has also been found to be strongly associated with cognitive reappraisal; the ability to monitor and assess negative thoughts and replace them with more positive ones to regulate emotions (McRae, Ciesielski \& Gross, 2012). Reappraisal does not always successfully reduce measures of negative emotion (Lam, Dickerson, Zoccola \& Zaldivar, 2009) and could be due to copings strategies implemented. It would suggest people who employ problem-focused coping strategies have increased resilience and less emotional impact of the traumatic event. However it is uncertain if cognitive appraisals are automatic processes or actively employed (Greenberg, 1995).

The process of cognitive appraisal could be impacted by self-efficacy, i.e. a person's perception that they can deal with life experiences. Positive self-efficacy can help individuals to assimilate their traumatic event, reduce stress reaction, improve coping and effectively manage their intrusive thoughts (Benight \& Bandura, 2004; Bandura, 1997). Individual's belief in their ability to cope, influences their vigilance towards potential threats and how they are perceived and cognitively processed. It can also decrease symptoms of stress (Andersson, Moore, Hensing, Krantz \& Staland-Nyman, 2014). Whereas the belief that the experience is unmanageable or that their coping strategies are ineffective, increases negative emotions to potential threats (Kleim, Vauth, Adam, Stieglitz, Hayward \& Corrigan, 2008; Lazarus \& Folkman, 1984). This research focussed on people experiencing mental illness and there may be mitigating factors in this population which are not controlled for. Higher selfefficacy increases effective coping strategies to manage stressors (Benight \& Bandura, 2004). Efficacy can regulate emotions as believing you can control a situation alleviates stress and anxiety which then allows individuals to cognitively process and use problem-focused coping (Benight \& Bandura, 2004). 
The purpose of the present study is to investigate the role that self-efficacy, resilience, coping and emotional reaction can have on a person's experience of trauma related intrusive thoughts. The following hypotheses will be investigated:

1. Those who utilise problem-focused coping will experience less emotional reactions to intrusion and have greater self-efficacy than those who utilise emotion-focused strategies.

2. Those who demonstrate greater resilience will utilise more problem-focused coping strategies and report less negative emotional reactions to intrusive thoughts than those who demonstrate less resilience.

3. Those who demonstrate greater self-efficacy will have lower scores on emotional reaction to intrusions than those who demonstrate lower self-efficacy.

4. Resilience will be predicted by self-efficacy.

\section{Method}

\section{Participants}

726 questionnaires were issued to young offenders. The sample was selected due to the high proportion of trauma in this population. Of these ,154 were returned, 2 of which were invalid. This gave a valid response rate of $20.94 \%$. The mean age of the participants was 19.11 years old $(\mathrm{SD}=1.192)$. The majority reported their ethnic origin as White Scottish (49\%, $\mathrm{n}=74)$. The remainder described themselves as White other $(25.2 \%, \mathrm{n}=38)$ or other (Black, Asian and Mixed Race; 3.3\%, $n=5) .22 .5 \%(n=34)$ did not report their ethnic origin.

\section{Measures}

The following measures were used and are described fully in Appendix A:

- Trauma History Questionnaire (THQ; Green, 1996)

- COPE Inventory (Carver, Scheier \& Weintraub, 1989)

- Emotional and Behavioural Reactions to Intrusions (EBRIQ; Berry et al, 2010)

- General Self-Efficacy Scale (GSE; Schwarzer \& Jerusalem, 1995)

- Impact of Event Scale (IES; Horowitz, Wilner \& Alvarez, 1979)

- Resilience Scale for Adults (RSA: Friborg, Hjemdal, Rosenvinge \& Martinussen, 2003) 


\section{Procedure}

Ethical approval was received from the Research and Ethics Committee of the Scottish Prison Service. The sensitive nature of the questionnaires focusing on trauma was clearly highlighted. Young offenders were approached in their residential hall with a consent form and questionnaire pack to their cell. Upon consenting they were given 24 hours to complete and return the questionnaire pack to the researcher at a designated time and place. All responses were anonymous and respondents were given a debrief sheet providing details of the study, researcher contact and relevant support services.

\section{Results}

\section{Data Screening}

Missing data was assessed as missing completely at random (Little (1988) MCAR Test: $\chi^{2}=2893.43(\mathrm{df}=3063 ; \mathrm{p}<.986)$ ). Missing data was replaced with group means (Tabachnick \& Fidell, 2007). Normality was assessed for each variable by inspecting histograms, skewness, kurtosis and the Shapiro-Wilk test. The IES and the EBRIQ did not show normal distribution therefore non-parametric statistics were used. The remaining variables revealed a normal distribution. Box plots did not indicate any extreme univariate or multivariate outliers, as measured by Mahalanobis Distances in regression analysis $(\mathrm{p}<$ 0.001 ) for the number of variables used in each analysis.

\section{Reliability}

Internal reliability was assessed. For the GSE scale coefficient $\alpha$ was .84 The COPE scale provided $\alpha$ of .841. The THQ scale coefficient $\alpha$ was .78 and for the IES $\alpha$ was .95 . The EBRIQ produced $\alpha$ of .85 and the RSA produced $\alpha$ of .91. Kline (2000) would suggest that .7 $\leq \alpha \leq .9$ represents good internal consistency and $\alpha \geq .9$ demonstrates excellent internal consistency. Therefore internal consistency was good for the scales used in this study.

\section{Extent of traumatic events}

The mean number of traumatic events in this sample was 6.64 per participant $(\mathrm{SD}=$ 3.816). 9 participants did not complete the THQ and this was accounted for by excluding cases pairwise. 3 participants indicated no traumatic life events, however this sample was too small to analyse as a separate group. As there could be unique differences in this group they 
were removed from the analysis. The sample was then split into 3 different trauma groups based on numbers of reported types of trauma: Group 1 (1-3 traumatic events; 23\%, $\mathrm{n}=35$ ), Group 2 (4-7 traumatic events; 35.6\%, $\mathrm{n}=54)$ and Group $3(8+$ traumatic events, $33.7 \%, \mathrm{n}=$ 51). Table 1 outlines the mean scores in each group across the measures used in this study.

Table 1

Mean scores for groups across measures

\begin{tabular}{lcccc}
\hline \multicolumn{1}{c}{ Measure } & \multicolumn{3}{c}{ Mean Scores } \\
& Group 1 & Group 2 & Group 3 \\
\hline Trauma History Questionnaire & 2.23 & 5.52 & 10.84 \\
General Self-Efficacy Scale & 26.23 & 27.48 & 26.3 \\
Resilience Scale for Adults & 86.83 & 76.46 & 85.61 \\
Problem-Focused Coping & & 42.83 & 45.28 & 43.12 \\
Emotion-Focused Coping & to Intrusions & 10.71 & 11.54 & 15.08 \\
Emotional \& Behavioural & Reaction & & & \\
Questionnaire & & 42.14 & 44.11 & 42.82 \\
Impact of Events Scale & & & 21.06 & 33.47 \\
\hline
\end{tabular}

\section{Differences across groups}

One-Way Analysis of Variance compared the mean scores for normally distributed scales across the trauma groups. No significant variances were found in group means for selfefficacy $(\mathrm{F}(2,138)=0.933, \mathrm{p}=0.396)$, resilience $(\mathrm{F}(2,98)=1.302, \mathrm{p}=0.277$, problemfocused coping $(\mathrm{F}(2,137)=0.25, \mathrm{p}=0.779)$ and emotion-focused coping $(\mathrm{F}(2,137)=$ $0.082, \mathrm{p}=0.921$ ). No significant difference was found between the mean scores for the trauma groups across these scales. This demonstrated that the number of traumatic events did not impact on the coping strategy used or the scores for self-efficacy or resilience.

A Kruskal-Wallis test was used to compare group means for non-normally distributed scales. There was a statistically significant difference for the Impact of Events Scales $\left(\chi^{2}\right.$ (2, $120)=8.78, \mathrm{p}=.012$ ) with the medians indicating participants who have most traumatic events had a significantly higher score (Group $3 \mathrm{Md}=45$; Group $1 \mathrm{Md}=21$, Group $2 \mathrm{Md}=$ 22). A statistically significant difference for the Emotional and Behavioural Reaction to Intrusions questionnaire $(\chi 2(2,127)=7.684, p=.021)$ was discovered with Group 3 
indicating a higher median score (group $3 \mathrm{Md}=18$; group $2=14$; Group $1=11$ ). This result indicates that those who have experienced the greatest amount of trauma are significantly more affected by the event and have a greater emotional and behavioural reaction to them.

\section{Impact of Trauma Group}

A series of two-way ANOVAS were conducted to investigate interaction effects between measures across trauma groups. Firstly the impact of coping strategy and number of traumas on emotional reaction to intrusions was considered. The interaction of problemfocused coping and number of traumas was not significant, $F(2,125)=1.115, p=0.331$. The main effects of trauma $(\mathrm{F}(2,125)=1.944, \mathrm{p}=0.148)$ and problem-focused coping $(\mathrm{F}(1$, $125)=0.376, p=0.541)$ were also not significant. There was no significant interaction effects for emotion-focused coping and number of traumas $(F(2,125)=0.616, p=0.542)$. There was no significant main effect for the individual factors either (Trauma: $F(2,125)=$ 2.045, $\mathrm{p}=0.134$; Emotion-focused coping: $\mathrm{F}(1,125)=0.012, \mathrm{p}=0.914)$. This therefore indicated that the type of coping strategy does not appear to significantly impact on a participant's emotional reaction to intrusions across trauma groups.

Table 2

Two-way ANOVA investigating interaction effects of trauma group and coping style on selfefficacy

Partial Eta

\begin{tabular}{llcccc}
\multicolumn{1}{c}{ Effect } & \multicolumn{1}{c}{ Factor } & F & df & Sig & squared \\
\hline Interaction & Trauma * emotion-focused coping & 0.543 & 2 & .582 & \\
Main & Trauma & .381 & 2 & .684 & \\
& Emotion-focused coping & 2.855 & 1 & .093 & \\
\multirow{2}{*}{ Interaction } & Trauma * problem-focused coping & .596 & 2 & .552 & \\
Main & Trauma & 1.445 & 2 & .239 & \\
& Problem-focused coping & 21.699 & 1 & .000 & .141 \\
\hline
\end{tabular}

Analysis of coping strategy and number of traumas on self-efficacy indicated no interaction effects for either coping strategy (Table 2). There was also no main effect for trauma or emotion-focused coping. However there was a significant effect found for 
problem-focussed coping $(\mathrm{F}(2,138)=21.699, \mathrm{p}=0.000)$ with the partial eta squared $(0.141)$ indicating a medium effect size (Cohen, 1988). The post-hoc comparisons indicate no difference in problem-focussed coping across trauma groups. However, this is not surprising as it agrees with the results from the one-way ANOVA above. A T-test was used, as only 2 levels of the independent variable, to compare self-efficacy in high and low problem-focused copers. The 2 groups varied significantly from each other with $\mathrm{t}(142)=-5.228, \mathrm{p}=0.000$. This indicated that those who have higher problem-focused coping have significantly higher self-efficacy than those with lower problem-focused coping.

Table 3

Two-way ANOVA investigating interaction effects of trauma group and coping style on resilience

Partial Eta

\begin{tabular}{llllll}
\multicolumn{1}{c}{ Effect } & \multicolumn{1}{c}{ Factor } & $\mathrm{F}$ & $\mathrm{df}$ & $\mathrm{Sig}$ & squared \\
\hline Interaction & Trauma * problem-focused coping & .187 & 2 & .830 & \\
Main & Trauma & 2.215 & 2 & .115 & \\
& Problem-focused coping & 18.816 & 1 & .000 & .171 \\
\multirow{2}{*}{ Interaction } & Trauma * emotion-focused coping & .655 & 2 & .522 & \\
Main & Trauma & 1.433 & 2 & .244 & \\
& Emotion-focused coping & 7.513 & 1 & .007 & .076 \\
\hline
\end{tabular}

On examining if coping style impacts on resilience across trauma groups there were no significant interactions effects found (Table 3). There were no significant main effects found for trauma. However there was a significant main effect discovered for both types of coping strategy with partial eta indicating a medium effect for problem-focused coping and a small-medium effect for emotion-focused coping. The post-hoc comparisons indicated no statistically significant difference for either coping style across trauma. T-tests explored the differences for resilience across coping strategies finding high problem-focused coping differed significantly from the low problem-focused coping $(\mathrm{t}(98)=-4.43, \mathrm{p}=0.000)$. This results was similar for emotion-focused coping $(\mathrm{t}(98)=-2.517, \mathrm{p}=0.013)$. This demonstrates that those who utilise more problem and emotion-focused coping have greater resilience scores. 
Table 4

Two-way ANOVA investigating interaction effects of trauma group and resilience on emotional reaction to intrusions

\begin{tabular}{lllllll}
\hline & & & & \multicolumn{3}{c}{ Partial Eta } \\
\multicolumn{1}{c}{ Effect } & Factor & F & df & Sig & squared \\
\hline Interaction & Trauma * resilience & 1.500 & 2 & .228 & \\
\multirow{2}{*}{ Main } & Trauma & 0.807 & 2 & .449 & \\
& Resilience & 23.67 & 1 & .000 & .201 \\
\hline
\end{tabular}

Analysis examining the impact that resilience has on participants emotional reaction to intrusions concluded there was no significant interaction effect (Table 4). There was no significant main effect of trauma, however, there was a significant main effect for resilience. The partial eta squared of .201 suggests that this factor has a medium to large effect size. The post-hoc comparisons demonstrate no significant difference across traumas. A T-test found that there was a significant difference between those who scored high or low on resilience and their score on emotional reaction to intrusions $(\mathrm{t}(120)=4.853, \mathrm{p}=0.000)$. This result indicates that individuals with lower resilience scores had increased emotional reaction to intrusive thoughts.

Table 5

Two-way ANOVA investigating interaction effects of trauma group and self-efficacy on emotional reaction to intrusions

Partial Eta

\begin{tabular}{llllll}
\multicolumn{1}{c}{ Effect } & \multicolumn{1}{c}{ Factor } & F & df & Sig & squared \\
\hline Interaction & Trauma * self-efficacy & 0.684 & 2 & .506 & \\
Main & Trauma & 2.263 & 2 & .108 & \\
& Self-efficacy & 17.458 & 1 & .000 & .127 \\
\hline
\end{tabular}

On examining the effect that trauma and self-efficacy has on emotional reaction to intrusions no significant interaction effect was found (Table 5). There was no significant main effect for trauma but there was for self-efficacy and the partial eta squared demonstrated that this was a medium effect size. The post hoc comparison found no significant different across trauma groups. A T-test assessed the difference between high and low self-efficacy 
scores. There was a significant difference between the self-efficacy groups ( $\mathrm{t}(129)=4.602$, $\mathrm{p}=0.000$ ) which means that participants with lower self-efficacy have higher emotional reactions to intrusions than those with higher self-efficacy.

\section{Relationships among variables}

A standard multiple regression analysis evaluated how the number of traumas, selfefficacy, coping style and emotional reaction to intrusions predicts resilience. All variables were retained as the correlations between each independent variables were less than 0.7 (Pallant, 2010). The Normal Probability Plot and the Scatterplot denoted no major deviations from normality or outliers in this sample.

Table 6

Summary statistics from the regression analysis to evaluate how independent variables predict resilience scores

\begin{tabular}{lcccc}
\hline \multicolumn{1}{c}{ Variable } & Beta $(\beta)$ & $\mathrm{p}$ & Part & \% of variance explained by \\
& -.72 & .351 & -.070 & 0.49 \\
\hline No. of Traumas & .327 & .001 & .248 & 6.15 \\
General Self-Efficacy & .195 & .071 & .137 & 1.88 \\
Problem-Focused Coping & .191 & .042 & .155 & 2.40 \\
Emotion-Focused Coping & -.265 & .003 & -.233 & 5.43 \\
EBRIQ & & & & \\
\hline
\end{tabular}

The independent variables above account for $47.5 \%\left(\mathrm{R}^{2}=.475\right)$ of the variance in resilience. It was found that self-efficacy (beta $=.327, \mathrm{p}<.01$ ) and emotional reaction to intrusions $($ Beta $=-.265, \mathrm{p}<.01)$ were significant unique predictors $($ Table 6$)$. Coping style (ProblemFocused Beta $=.195$, n.s.; Emotion-Focused Beta $=.191$, n.s. $)$ and number of traumas (Beta $=$ -.72 , n.s.) were not significant predictors. This would suggest that self-efficacy and emotional reaction to intrusions are factors which impact on an individual's resilience score. 


\section{Key summary of findings}

The number of traumatic events did not impact on the coping strategy used or the scores for self-efficacy or resilience. Participants experiencing the highest number of traumatic events have significantly higher scores on the impact of events scales and the emotional and behavioural reaction to intrusions. Emotional reaction to trauma related to intrusions does not significantly impact on coping strategy. Participants with higher selfefficacy demonstrated greater problem-focused coping strategies and less emotional reaction to intrusions than those with lower self-efficacy. Participants with greater resilience scores utilise more problem and emotion-focused coping strategies and experience less emotional reaction to their intrusions. Resilience was found to be predicted by self-efficacy and emotional reaction to intrusions.

\section{Discussion}

Over $90 \%$ of the sample reported experiencing at least one traumatic event. Over $33 \%$ of the sample experienced more than 8 types of traumatic event. This finding reinforces concerns about the amount of trauma young offender's experience. The high rates of multiple trauma is of particular concern for professionals who are engaging young offenders experiencing difficulties from trauma exposure (van der Kolk, 2005).

The number of traumatic events did not impact on the type of coping strategy, selfefficacy or resilience in young offenders. Those who had experienced the highest number of traumatic events appeared significantly more affected and had a greater emotional and behavioural reaction to their experience. This raises concerns in regard to the experiencing of multiple trauma creating difficulties. Although participants with more traumatic events report being more affected by the experience, the number of traumatic events does not dictate the coping strategy used. Resilience and self-efficacy are also not directly related to the number of traumas experienced which would suggest that there are other factors involved.

Contrary to expectations, there was no significant difference in emotional reaction to intrusions when considering coping styles. Overall, participants indicating an emotional reaction to intrusive thoughts did not exhibit a particular coping strategy. Emotional reaction could impact on ability to utilise effective coping strategies (Zamble \& Quinsey, 1997) or it 
could be that young offenders have not developed specific coping strategies due to adapting to situational factors. These adaptive coping strategies which were effective at the time of the trauma may have long term negative effects and would benefit from development into more effective coping strategies. The emotional reaction to intrusions could be limiting the participant's ability to process this experience effectively and therefore lead to choosing unhelpful coping methods (Clark, 2005; Berry, May, Andrade \& Kavanagh, 2010). This would suggest that building appropriate coping strategies at times of emotional arousal would help young offenders to better manage their traumatic experience.

Although the hypothesis that problem-focused copers will have greater self-efficacy than emotion-focused copers was not confirmed, higher self-efficacy was found in those who are greater problem-focused copers. This may suggest that people who use problem-focused coping have a greater belief in their ability to deal with intrusions. It could also be that young offenders with greater self-efficacy have developed coping strategies (either emotion or problem-focused) to adapt to their trauma related situation (Brown \& Ireland, 2006). Selfefficacy could enable participants to utilise more effective problem-focused coping strategies when dealing with intrusive thoughts (Benight \& Bandura, 2004). Using problem-focused coping may help participants feel more in control of their experience of intrusions and therefore more able to regulate emotions (Goldin et al, 2009). No main effect was found for emotion-focused coping in relation to self-efficacy. Research would suggest that emotionfocused coping responses are used to manage negative emotional reaction to stressors (Brown $\&$ Ireland, 2006) and it could be that self-efficacy does not mediate this initial adaptive strategy.

Confirming the prediction, participants who used problem-focused coping had greater resilience scores. This may indicate that they are more able to cognitively appraise situations and manage intrusive thoughts more effectively. Emotion-focused coping strategies were also associated with resilience. These strategies could be utilised in order to help individual's manage a situation adequately so that they have time to develop more effective coping strategies (Brown \& Ireland, 2006). It could also mean that emotion-focused coping strategies are used until individuals have more self-control to appraise the situation and change to more problem-focused coping strategies (Kashdan \& Rottenberg, 2010). Improving problemfocused coping would be favourable for long-term management as relying on emotion- 
focused coping could have negative long-term effects or be ineffective for other difficult situations (Brown \& Ireland, 2006).

Participants with lower self-efficacy had higher emotional reactions to intrusions than those with higher self-efficacy, confirming the hypothesis. This result could indicate that selfefficacy has a role to play in affective responses to trauma. It may be that belief in ability to manage the trauma response decreases the subsequent emotional reaction to the stressor. The affective reaction could impact on cognitive appraisal of the intrusive thought thus influencing confidence to effectively manage them (Clark, 2005; Berry et al, 2010). This supports research that developing self-efficacy could be a helpful intervention strategy for individuals who have experienced traumatic events (Benight \& Bandura, 2004).

Resilience was found to be predicted by self-efficacy and emotional reactions to intrusions. When considering multiple factors, $47.5 \%$ of resilience could be explained by self-efficacy, coping style, emotion reaction and number of trauma types. Unique contributors were self-efficacy $(6.15 \%)$ and emotional reaction (5.43\%). Other variables may not indicate as significant contributors due to overlap with other independent variables in the model (Pallant, 2010). This is especially true for coping strategies as individuals can implement both types when integrating and processing trauma experiences, with coping strategies being dependent on the type of traumatic event. However this was not explored. As almost half of resilience can be explained by the factors above practitioners could focus on these to increase individual's resilience in managing trauma related intrusions.

There are limitations in the current study which highlight future research avenues. Due to population composition, this study only considered young offenders who had experienced traumatic events in their life. Not enough participants had experienced no traumatic events to include this as a comparison group. It would be appropriate to examine the individual characteristics of offenders who report no trauma to explore any differences. In addition, the self-report nature of the study could introduce factors indicative of the group who returned the questionnaires. The $20.94 \%$ sample who returned the questionnaires may have done so due to interest in the topic because of their own experience of trauma or intrusive thoughts. 
The COPE inventory allows analysis of types of coping strategies however not an overall score on preference. Throughout the study there could have been an overlap with these two measures and in the future other methods of assessing coping style may be considered. Although the argument may always be that we use a range of coping styles dependent on the stressor. It could also be that coping style develops to manage the stressor over time and developing self-efficacy and resilience in order to encourage a more problemfocused approach would negate potential long term negative effects of ineffective coping strategies (Wu et al, 2013).

A strength of this study was its utility of a sample of young offenders who often report multiple traumatic events in their lives. There were limited differences across trauma groups suggesting that number of traumas is not significant in an individual's experience. It is inappropriate to make inferences about background or other individual factors without having explored this. Future research could examine whether certain characteristics enable some young offenders to better cope with traumatic life events. Personality, attitudinal and lifestyle factors should be researched to develop our understanding of individual differences that increase protective factors for trauma management.

This current study provides figures on the impact of certain psychological factors on male, predominantly white, young offender's experience of trauma related intrusions. Further research would benefit targeting females, a range of ethnicities and an adult population. Due to using an offender population who are at increased risk of experiencing trauma the individual characteristics which influence their experience may not be representative of the general population. Future research would benefit from considering locus of control as a mediating factor in dealing with trauma intrusions. This would be pertinent due to the role self-efficacy has in resilience and understanding how their perception of control impacts on this factor. It is important that understanding the factors which can support an individual to deal with traumatic events is developed more widely than the sample in this study.

\section{Implications for Practice}

- The number of traumatic events experienced should not be a condition for access to treatment.

- Interventions should focus on building strengths especially in self-efficacy and resilience. 
- It is also important to note that coping strategies may have been developed to manage certain types of stressors and be effective in the short-term. However they may not be appropriate for other situations or have long term negative effects. Therefore increasing problem-focused coping should be targeted in interventions. 


\section{References}

Abram, K.M., Teplin, L.A., Charles, D.R., Longworth, A.L., McClelland, G.M. \& Dulcan, M.K. (2004). Posttraumatic Stress Disorder and Trauma in Youth in Juvenile Detention. Archive of General Psychiatry, 61 (4), 403-410.

Abram, K.M., Teplin, L.A., King, D.C., Longworth, S.L., Emanual, K.M., Romero, E.G., McClelland, G.M., Dulcan, M.K., Washburn, J.J., Welty, L.J. \& Olson, N.D. (2013). PTSD, Trauma and Comorbid Psychiatric Disorders in Detained Youth. Juvenile Justice Bulletin: Office of Juvenile Justice and Delinquency Prevention.

American Psychiatric Association (2013). Diagnostic and statistical manual of mental disorders $\left(5^{\text {th }}\right.$ Ed). Arlington, VA; American Psychiatric Association.

Andersson, L,M.C., Moore, C.D., Hensing, G., Krantz, G. \& Staland-Nyman, C. (2014). General Self-efficacy and its relationship to self-reported mental illness and barriers to care: A General Population Study. Community Mental Health Journal, 50(6), 721-728.

Bandura, A. (1997). Self-Efficacy: the exercise of control. New York: Freeman.

Benight, C.C. \& Bandura, A. (2004). Social cognitive theory of posttraumatic recovery: the role of perceived self-efficacy. Behaviour Research and Therapy, 42, 1129-1148.

Berry, L., May, J., Andrade, J. \& Kavanagh, D. (2010). Emotional and behavioural reaction to intrusive thoughts. Assessment, 17(1), 126-137.

Brose, A., Schmiedek, F., Loveden, M. \& Lindenberger, U. (2011). Normal aging dampens the link between intrusive thoughts and negative affect in reaction to daily stressors. Psychology and Aging, 26(2), 488-52.

Brown, S.L. \& Ireland, C.A. (2006). Coping style and distress in newly incarcerated male adolescents, Journal of Adolescent Health, 38, 656-661. 
Burton, D., Foy, D., Bwanausi, C., Johnson, J., \& Moore, L. (1994). The relationship between traumatic exposure, family dysfunction, and post-traumatic stress symptoms in male juvenile offenders. Journal of Traumatic Stress, 7, 83-92.

Campbell-Sills, L., Cohan, S.L. \& Stein, M.B. (2006). Relationship of resilience to personality, coping and psychiatric symptoms in young adults. Behaviour Research and Therapy, 44, 585-599.

Carver, C.S. \& Scheier, M.F. (1994). Situational coping and coping in dispositions in a stressful transaction. Journal of Personality and Social Psychology, 66, 184-195.

Carver, C.S., Scheier, M. \& Weintraub, J. (1989). Assessing coping strategies: A theoretically based approach. Journal of Personality and Social Psychology, 56, 267-283.

Cauffman, E., Feldman, S. S., Waterman, J., \& Steiner, H. (1998). Posttraumatic stress disorder among female juvenile offenders. Journal of the American Academy of Child and Adolescent Psychiatry, 37, 1209-1216.

Clark, D.A. (2005). Thoughts in nonclinical individuals: Implications for clinical disorders. In D.A. Clark (Eds.) Intrusive thoughts in clinical disorders: Theory, research and treatment. The Guilford Press: New York.

Cohen, J. (1988). Statistical power analysis for the behavioral sciences (2nd ed.). Hillsdale, NJ: Lawrence Earlbaum Associates

Creamer, M., Burgess, P. \& Pattison, P. (1992). Reaction to Trauma: A Cognitive Processing Model. Journal of Abnormal Psychology, 101, 452-459.

Dunkley, D.N., Ma, D., Lee, I.A., Preacher, K.J. \& Zuroff, D.C. (2014). Advancing Complex Explanatory Conceptulizations of Daily Negative and Positive Affect: Trigger and Maintenance Coping Action Patterns. Journal of Counselling Psychology, 61 (1), 93-109. 
Eschlerman, K.J., Alacron, G.M., Lyons, J.B., Stokes, C.K. \& Schneider, T. (2012). The dynamic nature of the stress appraisal process and the infusion of affect. Anxiety, Stress and Coping: An international Journal, 25(3), 309-327.

Feder, A., Nestler, E.J. \& Charney, D.S. (2009). Psychobiology and molecular genetics of resilience. Nature Reviews Neuroscience, 10, 446-457.

Folkman, S. (2010). Stress, coping and hope. Psycho-Oncology, 19, 901-908.

Folkman, S. \& Lazarus, R.S. (1985). If it changes it must be a process: Study of emotion and coping on three stages of a college examination. Journal of Personality and Social Psychology, 48, 150-170.

Friborg, O., Hjemdal, O., Rosenvinge, J.H. \& Martinussen, M. (2003). A new rating scale for adult resilience: what are the central protective resources behind healthy adjustment? International Journal of Methods of Psychiatric Research, 12, 65-76.

Goldin, P.R., Mamber-Ball, R., Werner, K., Heimberg, R. \& Gross, J.J. (2009). Neural mechanisms of cognitive reappraisal of negative self-beliefs in social anxiety disorder. Biological Psychiatry, 66, 1091-1099.

Green, B. (1996). Trauma History Questionnaire. In B.H. Stamm (ed.), Measurement of stress, trauma and adaptation, 366-369: Lutherville, MD: Sidran Press.

Greenberg, M.A. (1995). Cognitive Processing of Traumas: The Role of Intrusive Thoughts and Reappraisals. Journal of Applied Social Psychology, 25 (14), 1262-1296.

Greenwald, R. (2002). The Role of Trauma in Conduct Disorder. Journal of Aggression, Maltreatment \& Trauma, 6(1), 5-23.

Harris, D. \& Howard, C. (2014). http://www.harrishoward.com/ Accessed on 25/05/15. 
Hooper, L.M., Stockton, P., Krupnick, J.L. \& Green, B.L. (2011). Development, Use and Psychometric Properties of the Trauma History Questionnaire. Journal of Loss and Trauma, $16,258-283$.

Horowitz, M., Wilner, N. \& Alvarez, W. (1979). Impact of event scale: A measure of subjective stress. Psychosomatic Medicine, 41, 209-218.

Kashdan, T.B. \& Rottenberg, J. (2010). Psychological Flexibility as a Fundamental Aspect of Health. Clinical Psychological Review, 30(7), 865-878.

Kleim, B., Vauth, R., Adam, G., Stieglitz, R-D., Hayward, P. \& Corrigan, P. (2008). Perceived stigma predicts low self-efficacy and poor coping in schizophrenia, Journal of Mental Health, 17(5), 482-491.

Kline, P. (2000). The handbook of psychological testing ( $2^{\text {nd }}$ ed.). London: Routledge.

Lam, S., Dickerson, S.S., Zoccola, P.M. \& Zaldivar, F. (2009). Emotion regulation and cortisol reactivity to a social-evaluative speech task. Psychoneuroendocrinology, 34, 13551362.

Lazarus, R.S. \& Folkman, S. (1984). Stress, appraisal and coping. New York, NY: Springer.

Little, R.J.A (1988). A Test of Missing Completely at Random for Multivariate Data with Missing Values. Journal of the American Statistical Association, 83 (404), 1198 - 1202.

Litz, B.T. (1992). Emotional numbing in combat related post-traumatic stress disorder: A critical review and reformulation. Clinical Psychology Review, 12, 417-432.

Lyubomirsky, S. \& Nolen-Hoeksema, S. (1995). Effects of self-focused rumination on negative thinking and interpersonal problem solving. Journal of Personality and Social Psychology, 69, 176-190.

Margolies, L. (2010). Understanding the Effects of Trauma: Post Traumatic Stress Disorder (PTSD). Psych Central. Accessed on November 28, 2014 from 
http://psychcentral.com/lib/understanding-the-effects-of-trauma-post-traumatic-stressdisorder-ptsd/0003971

McMackin, R., Morrissey, C., Newman, E., Erwin, B. \& Daley, M. (1998). Perpetrator and victim: Understanding and managing the traumatized young offender. Corrections Management Quarterly, 2, 36-45.

McRae, K., Ciesielski, B. \& Gross, J. (2012). Unpacking cognitive reappraisal: goal, tactics and outcomes. Emotion, 12, 250-255.

Moore, E., Gaskin, C. \& Indig, D. (2013). Childhood maltreatment and post-traumatic stress disorder among incarcerated young offenders. Child Abuse \& Neglect, 37(10), 861-870.

Nassif, Y. \& Wells, A. (2014). Attention Training Reduces Intrusive Thoughts Cued by a Narrative of Stressful Life Events: A Controlled Study. Journal of Clinical Psychology, 70(6), 510-517.

Nolen-Hoeksema, S., Parker, L. \& Larson, J. (1994). Ruminative coping with depressed mood following loss. Journal of Personality and Social Psychology, 67, 92-104.

Pallant, J. (2010). SPSS: A survival manual (4 ${ }^{\text {th }}$ edition). McGraw Hill: UK.

Rabois, D. \& Haafa, A.F. (2003). The influence of cognitive coping and mood on smokers' self-efficacy and temptation. Addictive Behaviours, 28, 561-573.

Reese, F.L., Kliewer, W. \& Suarez, T. (1997). Control Appraisals as Moderators of the Relationship between Intrusive Thoughts and Coping. Journal of Applied Social Psychology, 27 (13), 1131-1145.

Rivera, B., \& Widom, C. S. (1990). Childhood victimization and violent offending. Violence and Victims, 5, 19-35. 
Scholz, U., Gutiérrez-Doña, B., Sud, S. \& Schwarzer, R. (2002). Is general self-efficacy a universal construct? Psychometric findings from 25 countries. European Journal of Psychological Assessment, 18(3), 242-251.

Schwarzer, R. \& Jerusalem, M. (1995). Generalised Self-Efficacy Scale. In J.Weinman, S.Wright, \& M. Johnston, Measures in health psychology: A user's portfolio. Causal and control beliefs (pp. 35-37). Windsor, UK: NFER-NELSON.

Steiner, H., Garcia, I. G., \& Matthews, Z. (1997). Posttraumatic stress disorder in incarcerated juvenile delinquents. Journal of the American Academy of Child and Adolescent Psychiatry, 36, 357-365.

Sundin, E.C. \& Horowitz, M.J. (2002). Impact of Events Scale: Psychometric Properties. The British Journal of Psychiatry, 180, 205-209.

Tabachnick, B.G., \& Fidell, L.S. (2007). Using Multivariate Statistics, Fifth Edition. Boston: Pearson Education, Inc.

Troy, A.S., Wilhelm, F.H., Shallcross, A.J. \& Mauss, I.B. (2010). Seeing the silver lining: cognitive reappraisal ability moderates the relationship between stress and depressive symptoms. Emotion, 10, 783-795.

Van der Kolk, B.A. (2005). Child abuse and victimisation. Psychiatric Annals, 374-378.

Watson, C. G., Kucala, T., Manifold, V., Juba, M., \& Vassar, D. (1988). The relationship of post-traumatic stress disorder and adolescent illegal activities, drinking, and unemployment. Journal of Clinical Psychology, 44, 592-598.

Weiss, D.S. \& Marmar, C.R. (1997). The Impact of Event Scale - Revised. In Assessing Psychological Trauma and PTSD (eds. J.P. Wilson \& T.M. Keane), pp. 399-411. New York: Guilford Press.

Windle, G., Bennet, K.M. \& Noyes, J. (2011). A methodological review of resilience measurement scales. Health and Quality of Life Outcomes, 9(8), 1-18. 
Wu, G., Feder, A., Cohen, H., Kim, J.J., Calderon, S., Charney, D.S. \& Mathe, A.A. (2013). Understanding Resilience. Frontiers in Behavioural Neuroscience, 7(10), 1-15.

Zamble, E. \& Quinsey, V. L. (1997). The Criminal Recidivism Process. Cambridge, UK: Cambridge University Press.

Zeidner, M., \& Saklofske, D. (1996). Adaptive and maladaptive coping. In M. Zeidner, \& N. S. Endler (Eds.), Handbook of coping: Theory, research, and applications (pp. 505-531). Oxford, England: Wiley. 
Appendix A: Overview of the questionnaires utilised

\begin{tabular}{|c|c|c|c|c|c|c|c|c|}
\hline \multirow{2}{*}{$\begin{array}{l}\text { Measure } \\
\text { Name }\end{array}$} & \multirow{2}{*}{ Purpose } & \multirow{2}{*}{$\begin{array}{l}\text { No' of } \\
\text { Items }\end{array}$} & \multirow{2}{*}{$\begin{array}{l}\text { Examples } \\
\text { of Items }\end{array}$} & \multirow{2}{*}{$\begin{array}{l}\text { Response } \\
\text { Format }\end{array}$} & \multirow{2}{*}{ Scales Measured } & \multicolumn{2}{|c|}{ Internal Consistency } & \multirow{2}{*}{ Notes } \\
\hline & & & & & & Coefficient $\alpha$ & $\begin{array}{l}\text { Test-Retest } \\
\text { Reliability }\end{array}$ & \\
\hline $\begin{array}{l}\text { Trauma } \\
\text { History } \\
\text { Questionnaire } \\
\text { (THQ; Green, } \\
\text { 1996) }\end{array}$ & $\begin{array}{l}\text { Self-report } \\
\text { questionnaire } \\
\text { exploring } \\
\text { traumatic } \\
\text { occurrences }\end{array}$ & 24 & $\begin{array}{l}\text { "Have you } \\
\text { ever } \\
\text { received } \\
\text { news of a } \\
\text { serious } \\
\text { injury, } \\
\text { life- } \\
\text { threatenin } \\
\mathrm{g} \text { illness, } \\
\text { or } \\
\text { unexpecte } \\
\text { d death of } \\
\text { someone } \\
\text { close to } \\
\text { you? If } \\
\text { yes, please } \\
\text { indicate" }\end{array}$ & $\begin{array}{l}\text { This a data } \\
\text { collection } \\
\text { instrument, } \\
\text { with no } \\
\text { standard } \\
\text { scoring } \\
\text { method }\end{array}$ & & $\begin{array}{l}\text { As it is not an } \\
\text { orthodox } \\
\text { scale it was } \\
\text { not } \\
\text { appropriate to } \\
\text { establish } \\
\text { internal } \\
\text { consistency } \\
\text { (Hooper, } \\
\text { Stockton, } \\
\text { Krupnick \& } \\
\text { Green, 2011). }\end{array}$ & $\begin{array}{l}\text { Test-retest } \\
\text { reliability over a } \\
3 \text { month period } \\
\text { was good }(r= \\
70, \quad \text { Green, } \\
1996) .\end{array}$ & $\begin{array}{l}\text { Results generate a } \\
\text { total score } \\
\text { representing the } \\
\text { numbers and types } \\
\text { of events endorsed } \\
\text { including sub scale } \\
\text { scores, totalling } \\
\text { crime-related } \\
\text { events, general } \\
\text { disaster and } \\
\text { trauma, and } \\
\text { physical and sexual } \\
\text { incidents. }\end{array}$ \\
\hline $\begin{array}{l}\text { COPE } \\
\text { Inventory } \\
\text { (Carver, } \\
\text { Scheier \& } \\
\text { Weintraub, } \\
\text { 1989) }\end{array}$ & $\begin{array}{l}\text { Assesses both } \\
\text { dispositional } \\
\text { and situation- } \\
\text { specific coping } \\
\text { strategies }\end{array}$ & 60 & $\begin{array}{l}\text { "I talk to } \\
\text { someone } \\
\text { about how } \\
\text { I feel"; "I } \\
\text { use } \\
\text { alcohol or } \\
\text { drugs to } \\
\text { help me } \\
\text { through it" }\end{array}$ & $\begin{array}{l}\text { 4-point } \\
\text { Likert scale } \\
\text { with } \\
\text { answers } \\
\text { ranging } \\
\text { from } \\
\text { "I usually } \\
\text { don't do this } \\
\text { at all" to "I } \\
\text { usually do }\end{array}$ & $\begin{array}{l}13 \text { scales with } 5 \\
\text { representing } \\
\text { problem-focused } \\
\text { coping strategies and } \\
5 \text { representing } \\
\text { emotion-focused } \\
\text { coping strategies. }\end{array}$ & $\begin{array}{l}0.45 \text { to } 0.92 \\
\text { Stable } \\
\text { consistency. }\end{array}$ & $\begin{array}{l}\text { Relatively stable } \\
\text { over a } 8 \text { week } \\
\text { period. }\end{array}$ & $\begin{array}{l}\text { Individuals report } \\
\text { on the coping } \\
\text { strategies used in } \\
\text { response to } \\
\text { stressful events. }\end{array}$ \\
\hline
\end{tabular}




\begin{tabular}{|c|c|c|c|c|c|c|c|c|}
\hline & & & & $\begin{array}{l}\text { this a lot", } \\
\text { with no } \\
\text { neutral reply }\end{array}$ & & & & \\
\hline $\begin{array}{l}\text { Emotional and } \\
\text { Behavioural } \\
\text { Reactions to } \\
\text { Intrusions } \\
\text { (EBRIQ; } \\
\text { Berry et al, } \\
2010 \text { ) }\end{array}$ & $\begin{array}{l}\text { Evaluates the } \\
\text { emotional and } \\
\text { behavioural } \\
\text { reactions } \\
\text { intrusive } \\
\text { thoughts }\end{array}$ & 8 & $\begin{array}{l}\text { "It makes } \\
\text { me } \\
\text { anxious"; } \\
\text { "It } \\
\text { distracts } \\
\text { me from } \\
\text { what I am } \\
\text { doing". }\end{array}$ & $\begin{array}{l}\text { 5-point } \\
\text { Likert scale } \\
\text { with replies } \\
\text { ranging } \\
\text { from "never" to } \\
\text { "every } \\
\text { time" }\end{array}$ & $\begin{array}{l}\text { It has a 2-factor } \\
\text { structure } \\
\text { independently } \\
\text { measure the different } \\
\text { reactions to intrusive } \\
\text { thoughts, where } \\
\text { higher scores on } \\
\text { each subscale } \\
\text { indicate greater } \\
\text { reaction. }\end{array}$ & $\begin{array}{l}.86 \\
\text { Good } \\
\text { consistency. }\end{array}$ & $\begin{array}{l}\mathrm{r}=.68 \text { over a } 70 \\
\text { day period. } \\
\text { Good test-retest } \\
\text { reliability. }\end{array}$ & $\begin{array}{lr}\text { Higher } & \text { scores } \\
\text { indicate } & \text { greater } \\
\text { emotional } & \text { and/or } \\
\text { behavioural } & \\
\text { reaction. } & \end{array}$ \\
\hline $\begin{array}{l}\text { General Self- } \\
\text { Efficacy Scale } \\
\text { (GSE; } \\
\text { Schwarzer \& } \\
\text { Jerusalem, } \\
\text { 1995) }\end{array}$ & $\begin{array}{l}\text { Measures } \\
\text { perceived self- } \\
\text { efficacy } \\
\text { coping in } \\
\text { daily hassles as } \\
\text { well as after } \\
\text { stressful life } \\
\text { events. }\end{array}$ & 10 & $\begin{array}{l}\text { "I can } \\
\text { always } \\
\text { manage to } \\
\text { solve } \\
\text { difficult } \\
\text { problems } \\
\text { if I try } \\
\text { hard enough"; } \\
\text { "I can } \\
\text { usually } \\
\text { handle } \\
\text { whatever } \\
\text { comes my } \\
\text { way" }\end{array}$ & $\begin{array}{l}\text { 4-point } \\
\text { Likert scale } \\
\text { with } \\
\text { answers } \\
\text { from "Not at } \\
\text { all true" to } \\
\text { "Exactly } \\
\text { true" with } \\
\text { no neutral } \\
\text { reply }\end{array}$ & & $\begin{array}{l}.79 \text { to } .91 \\
\text { Good inter- } \\
\text { item } \\
\text { consistency }\end{array}$ & $\begin{array}{l}\mathrm{r}=.47 \text { to } .75 \\
\text { over a } 1 \text { to } 2 \\
\text { year period } \\
\text { (Scholz, } \\
\text { Gutiérrez-Doña, } \\
\text { Sud \& } \\
\text { Schwarzer, } \\
\text { 2002). } \\
\text { Average to good } \\
\text { reliability. }\end{array}$ & $\begin{array}{l}\text { Higher } \\
\text { indicate } \\
\text { perceived } \\
\text { efficacy. }\end{array}$ \\
\hline $\begin{array}{l}\text { Impact } \quad \text { of } \\
\text { Event Scale } \\
\text { (IES; } \\
\text { Horowitz, }\end{array}$ & $\begin{array}{lr}\text { Examines } & \text { the } \\
\text { subjective } & \\
\text { distress } & \text { from } \\
\text { exposure } & \text { to }\end{array}$ & 15 & $\begin{array}{l}\text { "I thought } \\
\text { about it } \\
\text { when I } \\
\text { didn't }\end{array}$ & $\begin{array}{l}\text { 4-point } \\
\text { Likert scale } \\
\text { with replies } \\
\text { varying }\end{array}$ & $\begin{array}{l}\text { Consists of two } \\
\text { subscales to measure } \\
\text { intrusion } \\
\text { avoidance }\end{array}$ & $\begin{array}{l}.86 \text { for the } \\
\text { intrusion } \\
\text { subscale; } \\
0.82 \text { for the }\end{array}$ & $\begin{array}{l}\mathrm{r}=.94 \text { and } .89 \\
\text { (over a } 6 \text { month } \\
\text { period) for the } \\
\text { intrusive and }\end{array}$ & $\begin{array}{lr}\text { Higher } & \text { scores } \\
\text { propose a more } \\
\text { extreme response } \\
\text { to the traumatic }\end{array}$ \\
\hline
\end{tabular}




\begin{tabular}{|c|c|c|c|c|c|c|c|c|}
\hline $\begin{array}{lr}\text { Wilner } & \& \\
\text { Alvarez, 1979) }\end{array}$ & $\begin{array}{ll}\text { major } & \text { life } \\
\text { events. }\end{array}$ & & $\begin{array}{l}\text { mean to"; } \\
\text { "Pictures } \\
\text { about it } \\
\text { popped } \\
\text { into my } \\
\text { mind" }\end{array}$ & $\begin{array}{lr}\text { from "not at } \\
\text { all" } \\
\text { "often", } \\
\text { with } \\
\text { neutral no } \\
\text { response }\end{array}$ & experience. & $\begin{array}{l}\text { avoidance } \\
\text { subscale } \\
\text { (Sundin \& } \\
\text { Horowitz, } \\
\text { 2002). } \\
\text { Good internal } \\
\text { consistency. }\end{array}$ & $\begin{array}{l}\text { avoidance } \\
\text { subscales } \\
\text { (Weiss \& } \\
\text { Marmar, 1997). } \\
\text { Good reliability. }\end{array}$ & incident. \\
\hline $\begin{array}{l}\text { Resilience } \\
\text { Scale for } \\
\text { Adults (RSA: } \\
\text { Friborg, } \\
\text { Hjemdal, } \\
\text { Rosenvinge \& } \\
\text { Martinussen, } \\
\text { 2003) }\end{array}$ & $\begin{array}{l}\text { Evaluates } \\
\text { interpersonal } \\
\text { and } \\
\text { intrapersonal } \\
\text { protective } \\
\text { factors } \\
\text { presumed to aid } \\
\text { adaptation to } \\
\text { psychosocial } \\
\text { difficulties. }\end{array}$ & 33 & $\begin{array}{l}\text { Statements } \\
\text { include } \\
\text { "When } \\
\text { something } \\
\text { unforeseen } \\
\text { happens - } \\
\text { I always } \\
\text { find a } \\
\text { solution or } \\
\text { I often feel } \\
\text { bewildere } \\
\text { d" }\end{array}$ & $\begin{array}{l}\text { 5-point } \\
\text { Likert scale } \\
\text { with replies } \\
\text { varying } \\
\text { from "The } \\
\text { statement on } \\
\text { the left is } \\
\text { most true } \\
\text { for me" to } \\
\text { "The } \\
\text { statement on } \\
\text { the right is } \\
\text { most true } \\
\text { for me" }\end{array}$ & & $\begin{array}{l}0.76 \text { to } 0.87 \\
\text { Good Inter- } \\
\text { item } \\
\text { consistency }\end{array}$ & $\begin{array}{l}r \quad>\quad 0.70 \\
\text { (Windle, } \\
\text { Bennett } \quad \& \\
\text { Noyes, 2011). } \\
\text { Good } \\
\text { Reliability. }\end{array}$ & $\begin{array}{l}\text { Higher scores } \\
\text { demonstrate that } \\
\text { individuals are } \\
\text { psychologically } \\
\text { healthier, better } \\
\text { adjusted and thus } \\
\text { more resilient }\end{array}$ \\
\hline
\end{tabular}

